\title{
STUDI KASUS PEMELIHARAAN AYAM BROILER PASCA COVID-19 DI DESA JAGERAGE KECAMATAN KURIPAN LOMBOK BARAT
}

\author{
Ni Made Andry Kartika ${ }^{1 *}$, Reno Adekamtari ${ }^{2}$ \\ ${ }^{1}$ Program Studi Peternakan, Fakultas Peternakan, Universitas Nahdlatul Wathan Mataram, Mataram, Indonesia \\ ${ }^{2}$ Program Studi Peternakan, Fakultas Peternakan, Universitas Nahdlatul Wathan Mataram, Mataram, Indonesia \\ *Email : andry.kartika@ymail.com
}

Diterima: 13 Januari 2021. Disetujui: 17 Maret 2021. Dipublikasikan: 26 April 2021

\begin{abstract}
ABSTRAK
Tujuan penelitian adalah untuk mengetahui pendapatan peternak yang diperoleh dari usaha ayam broiler selama Covid-19 dan untuk mengetahui kelayakan memelihara ayam broiler selama Covid-19. Penelitian ini dilaksanakan di Desa Jagerage Kecamatan Kuripan Lombok Barat Materi penelitian yang digunakan adalah Peternak Ayam Boiler. Penelitian ini menggunakan metode Survey yaitu dengan cara mengumpulkan data di lapangan melalui wawancara langsung dengan peternak menggunakan daftar pertanyaan yang telah disiapkan di dalam kuisioner. Variabel Penelitian yang diamati antara lain biaya tetap, biaya tidak tetap dan net R/C ratio. Analisis data yang digunakan adalah perhitungan pendapatan dan perhitungan kelayakan usaha (Soekartawi,1995). Hasil penelitian menunjukkan bahwa pendapatan usaha ayam broiler dengan populasi 5000 ekor ayam ras sebesar Rp. 85.225.500/periode, biaya yang dikeluarkan sebesar Rp. 99.856.850,- tidak layak dilakukan dengan nilai kelayakan usaha $(\mathrm{R} / \mathrm{C})$ sebesar 0.85 .
\end{abstract}

Kata Kunci : Ayam Broiler, Studi Kasus, Analisa Kelayakan

\begin{abstract}
The research objective was to determine the income of breeders obtained from the broiler chicken business during Covid-19 and determine the feasibility of raising broiler chickens during Covid-19. The location of this research is Jagerage, Kuripan, West Lombok. The material used in this research is Boiler Chicken Breeder. This research used the survey method by collecting data in the field through direct interviews with breeders using a list of questions in the questioner. The research variables observed were fixed costs, variable costs, and the net $\mathrm{R} / \mathrm{C}$ ratio. The data analysis is used to calculate income and calculate business feasibility (Soekartawi, 1995). The results show that the broiler chicken business income with a population of 5000 heads of chickens is Rp. 85,225,500/period, the costs incurred are Rp. 99,856,850., - not feasible to do with the business feasibility value (R/C) of 0,85.
\end{abstract}

Keywords: Broiler Chicken, Case Study, Feasibility Analysis

\section{PENDAHULUAN}

Kondisi pandemi yang terjadi diseluruh dunia pada awal tahun 2020 ini mengakibatkan dampak yang buruk diseluruh lini kehidupan. Dampak yang paling besar dirasakan terutama pada bidang ekonomi. Subsector peternakan yang juga merupakan salah satu penggerak dibidang ekonomi tentu juga mengamai dampak dari Covid-19 ini.

Pembangunan subsektor peternakan bertujuan untuk menyediakan pangan hewani berupa daging, susu, dan telur, meningkatkan pendapatan peternak, meningkatkan devisa dan memperluas kesempatan kerja, sehingga pada masa yang akan datang diharapkan dapat mem-berikan kontribusi yang nyata dalam pembangunan perekonomian bangsa.

Untuk meningkatkan penyediaan protein hewani asal ternak terutama daging ayam, maka peranan ayam broiler sebagai salah satu komoditi ternak penghasil daging sudah tidak disanksikan lagi. Hal ini karena ayam broiler memiliki percepatan tumbuh yang cepat dengan berat badan yang tinggi, sehingga mampu mengimbangi laju kebutuhan masyarakat yang semakin tinggi pula.

Disamping itu dengan harga yang lebih murah daging ayam dapat mensubtitusi kebutuhan daging yang berasal dari ternak besar maupun kecil (Cahyono,2001). Mengingat daging ayam telah menjadi suatu kebutuhan yang relative harus dijamin ketersediaan setiap hari, maka konsumsi akan terus meningkat. Perkiraan ini ditarik dan kondisi perekonomian masyarakat yang makin membaik dengan makin meningkatnya pendapatan per kapita (Anonim, 2000).

Lebih lanjut dikatakan bahwa peluang investasi agribisnis ayam broiler memiliki prospek yang cukup cerah untuk masa yang akan datang. Investasi ayam broiler di sub sektor peternakan sanagt prospektif karena terdapat beberapa kecenderungan yaitu : Daging unggas makin diminati oleh konsumen 
dengan alasan kesehatan, konsumsi daging per kapita lebih murah, produksi daging dalam negeri hamper seluruhnya dikonsumsi didalam neger behkan terjadi kekurangan suplay sehingga terjado impor dan daging ayam menempati posisi pertama dalam pemenuhan permintaan dan konsumsi daging. Suharno (2003), menyatakan bahwa perkembangan usaha ayam broiler tersebut didukung oleh makin kuatnya industry hulu seperti perusahaan pembibitan (breeding farm), perusahaan pakan ternak (feedmill), perusahaan obat hewan dan peralatan peternakan. Selain itu Suharno (2003) mengemukakan bahwa penentuan jumlah tenaga harus dilakukan secara hati - hati. Untuk peternakan ayam yang masih menggunakan peralatan manual, satu orang teknisi kandang mampu menangani 2.000 ekor ayam. Sedangkan dinegara yang sistem peternakan sudah serba otomatis, satu orang teknisi bisa menangani 8.000 ekor ayam.

Hanya saja, dengan kondisi pandemi Covid-19 ini apakah usaha dibidang ayam broiler ini masih bagus atau tidaknya perlu dilakukan studi kasus atau analisa usaha. Hal ini penting dilakukan dengan tujuan untuk mengetahui besarnya pendapatan yang diterima oleh peternak serta jumlah ternak yang diusahakan agar usaha tersebut dapat memberikan pendapatan yang layak atau tidaknya di era pandemi covid-19 ini.

\section{MATERI DAN METODE}

Penelitian ini dilaksanakan di Desa Jagerage Kecamatan Kuripan Kabupaten Lombok Barat. Adapun materi penelitian yang digunakan adalah Peternak Ayam Boiler. Penelitian ini dilaksanakan pada bulan april-juni pada saat kondisi pandemi covid-19 masuk ke Indonesia. Penelitian ini menggunakan metode Survey yaitu dengan cara mengumpulkan data di lapangan melalui wawancara langsung dengan peternak menggunakan daftar pertanyaan yang telah disiapkan.

Variabel penelitian yang diamati anatra lain; Biaya Tetap, Biaya Tidak tetap dan Net R/C Ratio. Metode analisis data yang akan digunakan adalah perhitungan pendapatan dan perhitungan kelayakan usaha (Soekartawi,1995) :

$$
\mathrm{JI}=\mathrm{TR}-\mathrm{TC}
$$

Keterangan :

$\mathrm{JI}=$ Pendapatan

$\mathrm{TR}=$ Total Revenue

$\mathrm{TC}=$ Total Cost

Untuk mengetahui layak tidaknya suatau usaha digunakan R/C Ratio yaitu dengan cara membandngkan tingkat pendapatan yang diperoleh dengan modal yang harus dikeluarkan.

\section{HASIL DAN PEMBAHASAN}

\section{Profil Peternakan}

Study kasus analisa usaha ayam boiler ini dilakukan di Desa Jagerage di Kecamatan kuripan Kabupaten Lombok Barat. di Desa Jagerage sendiri terdiri dari tujuh dusun terdapat dari Dusun Adeng, Dusun Karang Bucu, Dusun Bremi, Dusun Dsn Geres, Dusun Tegal, Dusun Lamper, Dusun Tibu Eleh. Pemeliharaan ayam broiler cukup banyak tersebar diberbagai dusun tersebut. Dari data BPS 2015 tercatat terdapat 36.699 ekor ayam boiler.

Disepanjang jalan desa Jagerage saja dapat dilihat jelas beberapa kandang besar yang merupakan tempat pemeliharan ayam potong atau boiler. Salah satunya adalah usah milik bapak Husni yang memulai usahanya sejak tahun 2015 silam. hingga saat ini usaha yang awalnya bermodal hanya satu kandang kecil telah berkembang dengan kapasistas saat ini sebesar 5000 ekor ayam potong per periode pemilahraan.

Bapak Husni terkadang dibantu oleh anaknya untuk membersihakan kandang agar sanitasi kandang selalu bersih. Untuk penjualan sendiri sudah ada biasa pengepul yang akan datang untuk mengambil hasil panennya sehingga tidak perlu hawatir dalam pemesarannya. 
AGRIPTEK : Jurnal Agribisnis dan Peternakan

Vol. 1 No.1, April $2021: 29-34$

\section{Pemeliharaan Ayam Boiler}

Ayam pedaging (broiler) adalah ayam yang sangat efektif untuk menghasilkan daging, karakteristik broiler bersifat tenang, bentuk tubuh besar, pertumbuhan cepat, bulu merapat ke tubuh, kulit dan produksi telur rendah (Susilorini, 2008). Usaha ayam pedaging (broiler) ini berkembang relative cepat sejak tahun 2006 sampai dengan tahun 2013 karena sebagian besar usaha ayam pedaging didukung oleh pengusaha kemitraan.

Persiapan kandang merupakan awal dari proses pemeliharaan ayam. Kenyamanan kandang sangat ditentukan oleh letak bangunan kandang. untuk memenuhi persyaratan, kandang dibangun jauh dari pemukiman, memenuhi syarat bagi kesehatan ternak karena berjauhan dengan kandang lainnya, sehingga ter-hindar dari penyebaran penyakit. Kandang yang digunakan terdiri dari 2 unit berbentuk panggung dengan meng-gunakan lantai dari bilahan bambu. Uku-ran 2 unit bangunan kandang masing-masing $8 \mathrm{~m}$ x 81 m dengan kapasitas 5000 ekor ayam, dan 8 x 28 m dengan kapasitas 2000 ekor. Setiap kandang terdiri dari sekat bambu dengan ukuran $8 \mathrm{~m}$ x $8 \mathrm{~m}$ dengan kapasitas 550 ekor. Sedangkan kapasitas untuk $1 \mathrm{~m}^{2}$ adalah $8-9$ ekor.

Peralatan kandangpun terbilang dapat digunakan dalam jangka waktu yang cukup lama yaitu bisa mencapai 5 tahun daya kegunaannya. Sedangkan peralatan kandang yang digunakan adalah sebagai berikut:

1. Tempat Pakan

Tempat pakan yang digunakan terbuat dari plastik sehingga mudah dibersihkan. Pada umur 1 - 9 hari tempat pakan yang digunakan berbentuk bulat (baki) seba-nyak 72 buah, sedangkan umur 10 sampai panen menggunakan tempat pakan gan-tung sebanyak 240 buah.

2. Tempat Air Minum

Tempat air minum terbuat dari plastik, dengan pengisian air secara otomatis, sehingga lebih efektif dan menghemat tenaga. Setiap kotak dalam kandang menggunakan 8 buah tempat minum.

3. Pemanas

Sumber panas berasal dari kompor minyak tanah yang dilengkapi dengan seng berbentuk lingkaran yang menye-rupai tudung. Seng berfungsi untuk me-nyebarkan panas dalam brooder. Pada umur ayam 1 - 2 hari, pemanas dinya-lakan 24 jam dengan suhu antara 35 - 390C. Pemanas dihentikan setelah ayang berumur 12 hari, dan disesuaikan keadaan suhu dalam kandang. Lampu hanya digunakan sebagai pene-rangan pada malam hari dalam kandang. Untuk kandang dengan kapasitas 5000 ekor menggunakan 38 buah balon dengan kekuatan 10 watt, sedangkan untuk kandang kapasitas 2000 ekor meng-gunakan 19 buah balon dengan kekuatan 10 watt.

Persiapan kandang yang baik menentukan berhasil tidaknya dalam pemeliharaan, mengingat kesehatan ternak juga tergantung dari kenyamanan hidupnya dalam kandang. Persiapan kandang dimulai dari pem-bersihan atau pencucian dari kotoran ternak sebelumnya, baik lantai kandang maupun kolong kandang. Untuk lebih menjamin kebersihan kandang, kolong kandang ditaburi kapur untuk membunuh jamur dan mikroba yang merugikan. Langkah selanjutnya adalah pemasangan tirai. Tujuan dari pemasangan tirai ini adalah untuk menjaga suhu dalam kandang serta menghindari cuaca buruk. Tirai dipasang sedemikian rupa untuk mempermudah membuka dan menutup apabila terjadi perubahan cuaca atau suhu dalam kandang, sehingga suhu dalam kandang dapat terjaga sesuai dengan kebutuhan ayam. Persiapan selanjutnya adalah pemasangan brooder (indukan), tempat pakan, dan tempat air minum. Tempat pakan dan tempat air minum dipasang secara berselang-seling. Sedangkan pemanas di-pasang di tengah-tengah brooder. Persiapan terakhir adalah fumigasi kan-dang. Bahan yang digunakan adalah formalin yang dicampur dengan air dengan dosis $1: 10$ lalu disemprotkan ke seluruh bagian kandang. Setelah semua persiapan kandang selesai, maka DOC siap dimasukkan

Dalam pemeliharaan ayam broiler, dikenal dua fase yaitu fase pemeliharaan starter (umur 1 hari - 3 minggu) dan fase pe-meliharaan finisher (umur 4 minggu sam-pai panen). Setelah DOC datang, hal yang harus dilakukan pertama kali menyalakan pemanas. Kemudian pemberian air 
minum yang dicampur dengan air gula merah untuk mengembalikan kondisi ayam dan mengobati stress selama perjalanan. Dan biarkan ayam minum selama 2 jam, setelah itu baru diberikan pakan sedikit demi sedikit. Pemberian pakan dilakukan 2 kali sehari yaitu pada pagi hari dan sore hari. Apabila air gula sudah habis, maka diganti dengan air biasa. Pada umur 2 hari brooder diperluas disesuaikan dengan pertumbuhan ayam.

Komposisi pakan pada umur starter adalah protein $23 \%$ dan ME $2.800-3.000 \mathrm{kkal}$. Kandungan gizi pakan akan lebih tinggi dibandingkan pada fase finisher, mengingat pada umur tersebut merupakan masa pertumbuhan dan pembentukan jaringan tubuh. Setelah ayam berumur 10 hari, tempat pakan dan air minum digantung. Brooder dilepas dan diganti dengan sekat yang terbuat dari bambu. Tirai dibuka setengah dan pada malam hari tirai kandang ditutup kembali. Pada umur 16 hari, alas kandang (litter) dilepas seluruhnya.

Fase finisher atau pemeliharaan masa akhir adalah fase dimana ayam berumur 4 minggu sampai panen. Yang berbeda pada pemeliharaan setiap fase adalah pem-berian pakan. Di mana pada fase ini kandungan gizi pakan yang dibutuhkan adalah protein $21 \%$ dan ME $3000-3200$ kkal. Kandungan protein relatif lebih rendah dibandingkan dengan fase starter, mengingat pada fase ini ayam telah mencapai titik akhir pertumbuhan. Sedangkan kandungan metabolisme energinya lebih tinggi untuk mencapai bobot badan yang maksimal pada saat dipa-sarkan. Pemberian pakan dilakukan 2 kali sehari, yaitu pada pagi hari dan sore hari. Sedangkan air minum diberikan secara adlibitum Selama proses pemeliharaan, kesehatan ayam perlu mendapatkan perhatian. Upaya yang dilakukan adalah melalui pemberian vitamin, obat-obatan dan vaksinasi yang teratur. Pemberian vitamin dilakukan apabila terjadiperubahan cuaca untuk menghindari terjadinya stress pada ayam. Sedangkan pemberian vaksin yaitu vaksin ND yang dicampur langsung dengan air minum dan diberikan pada pagi hari

\section{Analisis Usaha Ayam Boiler}

Analisis usaha merupakan bagian yang penting yang perlu dilakukan dalam suatu usaha agar dapat menghitung kebutuhan modal, biaya, dan pendapatan yang diperoleh. Adapun analisis dari usaha ayam broiler adalah, sebagai berikut :

Tabel 1. Besarnya Biaya Tetap yang Dikeluarkan untuk Populasi 5000 Ekor

\begin{tabular}{cccc}
\hline Biaya tetap & Jumlah & $\begin{array}{c}\text { thn penggunaan } \\
\text { (thn) }\end{array}$ & pnyst \\
\hline kandang 2 unit & 48.000 .000 & 10 & 4.800 .000 \\
\hline peralatan kandang & 27.500 .000 & 5 & 5.500 .000 \\
\hline Jumlah & 75.500 .000 & 15 & 10.300 .000 \\
\hline
\end{tabular}

Sumber data Primer : Diolah tahun 2020

Dari Table diatas terlihat bahwa biaya tetap yang dikeluarkan untuk pemeliharaan ayam broiler dengan jumlah populasi sebesar 5000 ekor adalah Rp.75.500.000,-/periode pemeliharaan. Biaya ini terbilang cukup tinggi . Tingginya biaya tetap ini adala disebabkan karena tingginya harga pembuatan kandang dan peralatan kandang yang digunakan. Semakin tinggi harga pembuatan kandang maka semakin lama penggunaannya. ini terlihat dari nilai penyusutan peralatan hingga mencapai 10 tahun masih bisa digunakan. 
AGRIPTEK : Jurnal Agribisnis dan Peternakan

Vol. 1 No.1, April $2021: 29-34$

Tabel 2. Besarnya Biaya Tidak Tetap yang Dikeluarkan untuk Populasi 5.000 Ekor

\begin{tabular}{cc}
\hline Biaya Variabel & Jumlah \\
\hline DOC & 25.000 .000 \\
\hline Pakan & 59.966 .850 \\
\hline Obat2an & 1.000 .000 \\
\hline Minyak Tanah & 720.000 \\
\hline Gula Merah & 15.000 \\
\hline Sekam & 300.000 \\
\hline Formalin & 55.000 \\
\hline Tenaga Kerja & 2.500 .000 \\
\hline Jumlah & $\mathbf{8 9 . 5 5 6 . 8 5 0}$
\end{tabular}

Sumber data Primer : Diolah tahun 2020

Dari Table 2 terlihat bahwa biaya variable yang dilekuarkan oleh petrnak ayam broiler mencapai Rp.89.556.850,-/peride pemeliharaan. Harga DOC (Day OLD Chick), pakan serta biaya tenaga kerja yang cukup tinggi cukup mempengaruhi biaya variable ini.

Total Biaya produksi adalah Total seluruh biaya yang dikeluarkan selama proses pemeliharaan berlangsung.

Tabel 3 . Total Biaya Produksi yang dikeluarkan oleh Peternak Ayam Broiler

\begin{tabular}{ccc}
\hline & Total Biaya & \\
Parameter Yang Diamati & & Jumlah $(\mathrm{Rp})$ \\
Biaya Tetap & & 10.300 .000 \\
Biaya Tidak Tetap & 89.556 .850 \\
Jumlah (Rp) & $\mathbf{9 9 . 8 5 6 . 8 5 0}$ \\
Harga / Kg hidup & Total Pendapatan & 10.000 \\
Jumlah ternak yg dijual (ekor) & 4870 \\
Berat rata - rata yang dipanen (kg) & 1,75 \\
Jumlah (Rp) & $\mathbf{8 5 . 2 2 5 . 5 0 0}$ \\
Pengeluaran - pendapatan (Rp) & $\mathbf{- 1 4 . 6 3 1 . 3 5 0}$ \\
\hline
\end{tabular}

Panen dilakukan pada umur 32 - 36 hari, di mana ayam sudah mencapai berat rata-rata 1,75 $\mathrm{kg} / \mathrm{ekor}$. Dari data produksi diperoleh hasil penjualan sebanyak 4870 ekor dengan tingkat mortalitas 1,87\% (130 ekor). Besarnya rata-rata pendapatan peternak ayam broiler itu disebabkan karena penerimaan lebih besar selain itu juga disebabkan karena jumlah mortalitas yang cukup rendah dan harga persatuan produk yang tinggi yaitu Rp. 10.000,-. Pada bulan april lalu disaat covid-19 masuk ke Indonesia.

\section{Kelayakan Usaha Ternak Ayam Broiler}

Salah satu criteria kelayakan usaha yakni dengan melihat nilai $\mathrm{R} / \mathrm{C}$ ratio merupakan perbandinganantara total biaya produksi dengan total penerimaan selama usaha. Hasil peneitian diperolrh bahwa total penerimaan sebesar $\mathrm{Rp}$. 85.225.500,- sedangkan total biaya sebesar Rp 99.856.850,- sehingg dengan menggunakn rumus R/C dengan formulasi sebagai berikut :

$$
\frac{85,225.500}{99,856,850}=0,85
$$

Nilai ini menunjukkan bahwa usaha ternak ayam broiler di daerah tersebut secara ekonomis tidak layak diusahakan krena setiap Rp 100,- biaya yang dikeluarkan oleh peternak akan menghasilkan penerimaan sebesar Rp 0,28,-. Hal ini tentu diakibatkan kondisi pandemic Covid-19 yang mengakibatkan permintaan sedikit sementara panenx melimpah.

\section{KESIMPULAN}

Dari hasil studi kasus yang telah dilakukan diperoleh simpulan bahwa pendapatan usaha ayam broiler dengan populasi 5000 ekor adalah Rp. 85.225.500/periode, biaya yang dikeluarkan sebesar Rp. 99.856.850.,- tidak layak untuk dilakukan dengan niai kelayakan usaha (R/C) sebesar 0,85. 
AGRIPTEK : Jurnal Agribisnis dan Peternakan

Vol. 1 No.1, April $2021: 29-34$

\section{DAFTAR PUSTAKA}

Anonim, 2000. Investasi Agribisnis Komoditas Unggulan Peternakan. Badan Agribisnis Deptan Bekerja sama dengan Kanisius, Jakarta.

Anonym.2020.https://www.lampost.co/berita-dampak-covid-19-bagi-sektor-perekonomian-di-indonesiaserta-kebijakan-pemerintah-untuk-meningkatkan-stabilitas-ekonomi-nasional.html

Cahyono, B, 2001. Cara Meningkatkan Budidaya Ayam Ras Pedaging.

El-kabumaini, N., dan S.R. Tjetje, 2008. Beternak ayam pedagingdan petelur. Puri Pustaka. Bandung

Soekartawi, 1995. Analisis Usahatani. Universitas Indonesia Press, Jakarta.

Suharno, B. 2003. Kiat Sukses Berbisnis Ayam. PT. Penebar Swadaya, Jakarta. 